\title{
JUURNAL.RU
}

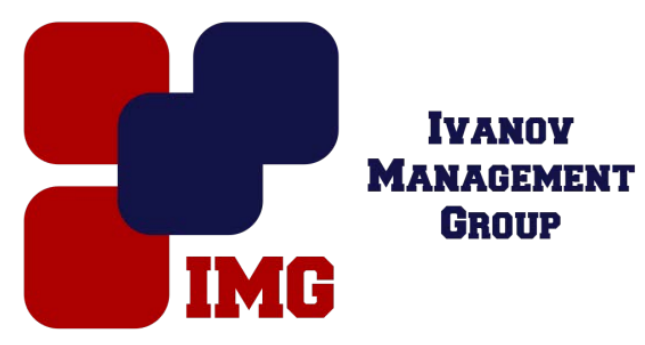

Петров Д.А. Институт рекреаџии, туризма и физической культуры БФУ им. И.Канта Калининград, Россия

doi: 10.18411/lj-30-04-2017-2-04

idsp 000001:lj-30-04-2017-2-04

\section{Социально-психологические трудности учителей в условиях инклюзивного образования}

\section{Аннотация}

Данная статья посвящена проблемам развития инклюзивного образования в образовательных организациях. По мнению автора статьи, основная проблема, перед которой оказываются образовательные организации, заключается в отсутствии системы подготовки педагогических кадров к работе с детьми с особыми возможностями здоровья. В статье описываются особенности профессиональных и психологических препятствий педагогов инклюзивного образования. Автор пытается определить пути выхода из сложившейся ситуации путем развития основных профессиональных компетенций учителя, работающего в системе инклюзивного образования.

Ключевые слова: инклюзивное образование, профессиональный барьер, психологический барьер, профессиональная компетентность.

В соответствии с Конституцией Российской Федерации и Законом «Об образовании в Российской Федерации» от 29.12.2012 г. № 273-Ф3, дети с ограниченными возможностями здоровья имеют равные со всеми права на образование. Согласно статье 2 закона об образовании, инклюзивное образование - обеспечение равного доступа к образованию для всех обучающихся с учетом разнообразия особых образовательных потребностей и индивидуальных возможностей. Инклюзивное образование стремится развить методологию, направленную на детей и признающую, что все дети - индивидуумы с различными потребностями в обучении. Инклюзивное образование старается 
разработать подход к преподаванию, который будет более гибким для удовлетворения различных потребностей в обучении.

Однако перед школами встают не только и даже не столько материальнотехнические, сколько социально-психологические проблемы. И одна из них субъективные трудности педагогических коллективов общеобразовательных школ к работе в новых условиях. Об этой проблеме написано достаточно много (С.В. Алехина, М.А. Алексеева, М.С. Староверова, Т.И. Шамова, Н.Е. Щуркова и др.). С.В. Алехина указывает на то, что важная характеристика данногоэтапа развития инклюзивного образования - недостаточная профессиональная подготовка педагогов общего образования и специалистов сопровождения, способных реализовать инклюзивный подход [1]. Заметим, что, несмотря на различие подходов к определению психологической готовности к деятельности, большинство авторов исходят из общей позиции о том, что психологическая готовность является сложным синтетическим образованием, состоящим из комплекса разнообразных, связанных между собой элементов [1].

К проблеме работы учителей в условиях инклюзивного образования так же обращались Е.Л. Агафонова, М.Н. Алексеева, Е.Н. Кутепова и др. Они приходят к выводу, что по сути, психологическая работа педагогов массовых школ в процессе включения детей с инвалидностью в образовательный процесс направлена на преодоление основного психологического барьера - страха перед неизвестным, страха вреда инклюзии для всех остальных участников образовательного процесса[2].

Такие негативные установки и предубеждения, профессиональная неуверенность учителя, нежелание изменяться, психологическая неготовность к работе с «особыми» детьми не могут не влиять на создание инклюзивной среды, инклюзивной культуры. Принято считать, что психологические трудности в школе могут быть только у ученика. Такие социальные изменения в образовании, как инклюзия, показывают, что много психологических проблем имеется у самого учителя.

Значимым условием внедрения и развития инклюзивного образования, по мнению отечественных (С.В. Алехина, Е.Н. Кутепова, Н.Я. Семаго, Т.Ю. Четверикова, И.М. Яковлева и др.) и зарубежных (J.Corbet, V.Volonino, N.Zigmond и др.) исследователей, является подготовка компетентных педагогов, способных и готовых эффективно работать с детьми, имеющими ограниченные возможности здоровья (ОВ3).

Данные исследователи так же рассматривают готовность педагогов к 
инклюзивному образованию через преодоление психологических барьеров[2].

В структуре профессиональной готовности авторы выделяют следующие компоненты: владение педагогическими технологиями, знание основ коррекционной педагогики и специальной психологии, информационную готовность, вариативность и гибкость педагогического мышления, учет индивидуальных различий детей, рефлексию профессионального опыта и результата, готовность к профессиональному взаимодействию. В структуре психологической готовности вычленяются: мотивационная готовность, состоящая из личностных установок (нравственные принципы педагога и сомнения в отношении инклюзии); эмоциональное принятие детей с различными нарушениями в развитии (принятие - отторжение); готовность включать таких детей в образовательную деятельность (включение - изоляция).

Авторами делается акцент на том, что первичным и важнейшим этапом подготовки педагогов к реализации инклюзии является этап психологических и ценностных изменений и уровня профессиональных компетентностей еe специалистов.

Под психологической готовностью педагога к реализацииинклюзивного подхода в образовании С.В. Алёхина и Л.П. Фальковскаяпонимают сложное, целостное, личностное образование, представляющее совокупностьсоциальных, нравственных, психологических и профессиональныхкачеств и способностей, позволяющих на высокоммотивационном уровне обеспечивать возможность результативнойдеятельности по включению ребёнка с особыми образовательнымипотребностями в учебное взаимодействие с другимиучастниками образовательного процесса[1].

Им так же удалось определить некоторые её составляющие относительно реализации инклюзивного подхода в условиях общего образования:

- эмоциональное принятие детей с различными типаминарушений в развитии, которое определяется степенью выраженностиэмоциональных затруднений учителя в процессевключения;

- мотивационные установки, нравственные принципы, ценностносмысловые установки восприятия «другого»,определяющие отношение к идее инклюзии. Такие установкиформируют внутреннюю мотивацию на обогащение другимопытом, желание познавать и развивать инклюзию. 
- личностная готовность, воплощённая в личностных установках на ученика с инвалидностью, внутренняя детерминация активности личности педагога [3].

В работах А.С. Сиротюк структура профессиональной компетентности представлена следующими ее составляющими:

1. Профессионально-специализированные компетенции: способность и готовность педагогов к использованию полученных знаний, умений и навыков для решения практических задач в системе инклюзивного образования; к формированию толерантного отношения общества к детям с ОВЗ; к организации просветительской и пропедевтической работы по вопросам инклюзии; к созданию единой обогащенной образовательной среды для детей с ОВ3; к организации полисубъектной помощи родителям таких детей по ориентации в правовых, социальных, медицинских и психолого-педагогических вопросах; к инклюзивному психическому развитию и социализации детей с ОВ3.

2. Основные профессионально значимые качества личности: высокий уровень развития мотивационной готовности к работе с детьми с ОВ3; потребность в профессиональном и личностном саморазвитии; эмпатийность; фасилитативные и коммуникативные способности.

3. Профессионально-личностная позиция: создание толерантной, вариативной, обогащенной и индивидуализированной образовательной среды для детей с ОВ3 [4].

Таким образом, эмпирический портрет учителя инклюзивногообразования позволяет оптимизировать психологическую подготовку данной категориипедагогов, предусмотреть для них специальные тренинги личностного роста, толерантности и другие. Только в этом случае нам удастся в полной мере подготовить учителей к работе с детьми с особыми образовательными потребностями в общеобразовательной школе. Авторамитакже рассматривается идеяединой системыподготовки,когда при исключении одной составляющей (например, полисубъектной помощи родителям) невозможно полноценно организовать инклюзию в образовательном пространстве детского сада или общеобразовательной школы [5]. 


\section{Литература}

1. Алехина, С. В. Готовность педагогов как основной фактор успешности инклюзивного процесса в образовании / С.В. Алехина, М.Н. Алексеева, Е.Л. Агафонова // Психологическая наука и образование. - 2011. - № 1. - С. 83-92.

2. Кутепова, Е. Н. Готовность педагога к деятельности в условиях инклюзивной практики / Е.Н. Кутепова, Ж.Н. Черенкова // Инклюзивное образование: практика, исследования, методология: сборник материалов II Междунар. науч.-практ.конф. Москва, 2013. - С. 588-592.

3. О.С. Кузьмина, Н.В. Чекалева, Т.Ю. Четверикова. Организация и содержание подготовки педагогов к деятельности в условиях инклюзивного образования: монография /- Омск: Издатель-Полиграфист, 2014. - 242 с.].

4. Сиротюк, А. С. Организация полусубъектной деятельности специалистов в системе инклюзивного образования / А.С. Сиротюк // Almamater: Вестник высшей школы. 2012. - № 4. - C. 66-70].

5. Четверикова, Т.Ю. Теоретическая готовность педагогов к работе в условиях инклюзивного образования // В мире научных открытий. - 2014. - № 5.1(53). - С. 475485]. 